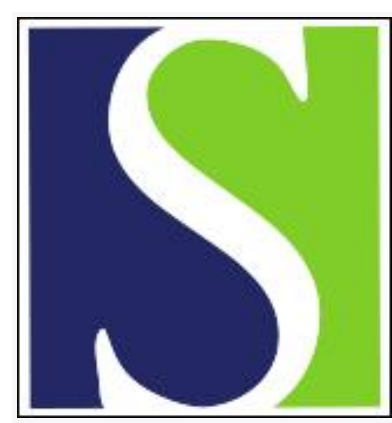

Scand J Work Environ Health 1988;14(3):181-188

https://doi.org/10.5271/sjweh.1933

Issue date: Jun 1988

An 11-year longitudinal study of the occupational dust exposure and lung function of polyvinyl chloride, cement and asbestos cement factory workers.

by Siracusa A, Forcina A, Volpi R, Mollichella E, Cicioni C, Fiordi T

Affiliation: Institute of Occupational Medicine, University of Perugia, Italy.

This article in PubMed: www.ncbi.nlm.nih.gov/pubmed/3393854 


\title{
An 11-year longitudinal study of the occupational dust exposure and lung function of polyvinyl chloride, cement and asbestos cement factory workers
}

\author{
by Andrea Siracusa, MD, ${ }^{1}$ Antonio Forcina, $\mathrm{PhD},{ }^{2}$ Roberto Volpi, MD, ${ }^{3}$ Emanuela Mollichella, MD, ${ }^{1}$ \\ Carla Cicioni, MD, ${ }^{1}$ Tiziana Fiordi, MD ${ }^{1}$
}

\begin{abstract}
SIRACUSA A, FORCINA A, VOLPI R, MOLLICHELLA E, CICIONI C, FIORDI T. An 11-year longitudinal study of the occupational dust exposure and lung function of polyvinyl chloride, cement and asbestos cement factory workers. Scand $J$ Work Environ Health 14 (1988) 181-188. Standardized questionnaires and lung function tests were administered in 1973,1980, and 1984 to 126 workers occupationally exposed to polyvinyl chloride (PVC) dust, to cement dust, or to asbestos cement dust until 1974-1978 and to PVC thereafter. The workers in the last group were assigned to two asbestos exposure categories (heavy and slight). The decline in forced vital capacity (FVC) and forced expiratory volume in $1 \mathrm{~s}\left(\mathrm{FEV}_{1.0}\right)$ was analyzed with regard to the length of time since the date of first employment. After adjustment for age, height, and smoking status at the date of first employment, the decline in FVC and $\mathrm{FEV}_{1.0}$ among the nonsmokers-light smokers was slightly accelerated with length of employment in the PVC and slight asbestos exposure groups and markedly accelerated with time since first employment in the heavy asbestos exposure group. The heavy smokers in all the exposure groups had FVC and FEV ${ }_{1.0}$ predicted values that were lower than those of the nonsmokers-light smokers; these differences remained constant with length of employment. Cessation of asbestos exposure for about 10 years did not seem to change lung function decline.
\end{abstract}

Key terms: asbestos and smoking interaction, asbestos exposure, lung function after cessation of asbestos exposure, lung function change, total dust concentration.

The effect of asbestos exposure on lung function has been reported in several cross-sectional $(10,12,17-19$, $22)$ and a few longitudinal $(2,11,13,20,21)$ studies. The latter have usually been based on two surveys.

In 1973 a longitudinal study was begun on the respiratory symptoms and lung function of workers occupationally exposed to polyvinyl chloride (PVC), cement, and asbestos cement dust $(25,26)$. In two previous studies regarding the period from 1973 to 1980 , after adjusting for smoking habits, we showed that those exposed to asbestos had a faster decline in forced vital capacity (FVC) and forced expiratory volume in $1 \mathrm{~s}\left(\mathrm{FEV}_{1.0}\right)$. The combined effect of dust and cigarette smoking seemed less than additive with asbestos or cement exposure.

A third survey was carried out in 1984 with the purpose of studying (i) the lung function decline in workers exposed to PVC or cement or with previous exposure to asbestos cement dust; (ii) whether the decline was linear or not; (iii) the effect of cigarette smoking, if additive or synergistic, on each exposure group; (iv) whether a change in lung function decline occurred after the cessation of asbestos exposure; and (v) the pos-

\footnotetext{
I Institute of Occupational Medicine, University of Perugia, Perugia, Italy.

2 Institute of Statistics, University of Perugia, Perugia, Italy.

${ }^{3}$ Occupational Medicine Section, ULSS Alto Chiascio, Gubbio, Italy.
}

Reprint requests to: Dr A Siracusa, Institute of Occupational Medicine, University of Perugia, 1-06100 Perugia, Italy. sibility of discriminating between the effect of age and the effect of the length of exposure.

\section{Subjects and methods}

\section{The production processes}

The subjects came from two establishments. One began manufacturing two different building materials in 1963, PVC and asbestos cement. Between 1974 and 1978 the asbestos cement production was progressively reduced, and the workers were gradually transferred to the PVC department. The plant stopped manufacturing asbestos cement products in December 1978. The other establishment has been manufacturing cement since 1957.

The asbestos cement and PVC production processes have been described in detail elsewhere (25). On the basis of a previous evaluation of dust exposure in asbestos cement manufacturing operations (9), we defined the mixing and grinding areas as heavy asbestos exposure, and all the other asbestos cement areas as slight asbestos exposure.

In the cement production marlstone was excavated from a nearby open pit quarry by shot blasting and mechanical fragmentation. The marl was then conveyed to the establishment, crushed, and ground. Clinker was obtained by calcination at about $1440^{\circ} \mathrm{C}$. Small amounts of such materials as gypsum, natural pozzolan, and marl were added to the clinker, and the 
mixture was then ground in steel ball mills. The finished cement was pumped into storage silos and then delivered to the customer in machine-sealed cement bags or tank trucks.

\section{Enxironmental analysis}

In 1973 the total dust level was determined in 10 areas of the PVC department, six sampling points in the asbestos-cement mixing area, and 13 areas of the cement factory. Another environmental analysis was carried out in 1978 in 31 areas of the cement factory. The area samples were collected on a membrane filter through which air was pumped at a flow rate of $18-20$ $1 / \mathrm{min}$. The sampling time was 30 to $90 \mathrm{~min}$. Cellulose ester filters were used with a diameter of $50 \mathrm{~mm}$ and a pore size of $0.8 \mu \mathrm{m}$.

\section{Subjects}

The 1973 and 1980 surveys of the workers employed in PVC and asbestos cement production have been described in detail elsewhere (25). The same methodology was used as for the 1973 and the 1980 surveys on cement workers and the 1984 survey on all the employment groups.

Table 1 shows the subjects studied in 1973. The asbestos workers were assigned to the heavy exposure group when they had been working one year or more

Table 1. Subjects participating in the study by year of study and by type of exposure.

\begin{tabular}{|c|c|c|c|c|c|c|}
\hline \multirow{2}{*}{$\begin{array}{l}\text { Type of } \\
\text { exposure }\end{array}$} & \multicolumn{2}{|c|}{1973} & \multicolumn{2}{|c|}{$\begin{array}{c}1973 \text { and } \\
1980\end{array}$} & \multicolumn{2}{|c|}{$\begin{array}{c}1973,1980 \\
\text { and } 1984\end{array}$} \\
\hline & $\mathrm{N}$ & $\%$ & $\mathrm{~N}$ & $\%$ & $N$ & $\%$ \\
\hline $\begin{array}{l}\text { Polyvinyl } \\
\text { chloride }\end{array}$ & 34 & 100 & 30 & 88.2 & 29 & 85.3 \\
\hline Cement & 68 & 100 & 47 & 69.1 & 36 & 52.9 \\
\hline Asbestos a & 77 & 100 & 65 & 84.4 & 61 & 79.2 \\
\hline
\end{tabular}

a Asbestos exposure ceased between 1974 and 1978. in the mixing or grinding areas between 1963 and 1978. Thirteen subjects had been working in the mixing and grinding areas for a mean employment duration of 7.6 (SD 5.5, range 1-15) years. All the other asbestos workers (48 subjects) were assigned to the slight exposure group. There was a higher number of subjects lost to follow-up in the cement group because we made only one attempt to find them. From the 1973 to the 1984 survey there were six deaths among the asbestos workers and five among the cement workers; eight subjects were untraceable; and 34 subjects, of whom 27 were cement workers, refused to participate. Among the 27 cement workers who refused to participate, 21 had retired, 11 before the normal retirement age of 60 years. One subject, who participated in the 1973 and 1980 surveys, was excluded because of bronchial asthma (25).

\section{Data analysis}

The analysis of the results of the pulmonary function tests was based on a set of linear regression models in which the intercept term contained a random effect associated with each subject. Several preliminary models were fitted to the data aimed at comparing the lung function decline in time among the four exposure groups, after adjustment for height and smoking status. However, because such a decline is related both to the effect of aging and to that of exposure, two separate variables were considered, ie, age at the date of first employment and length of time from that date (which can be treated as a measure of exposure within each group). The use of this procedure was possible because the age at the date of first employment varied greatly among the workers (table 2). Moreover, the need to create three age groups emerged during the preliminary analysis as a simple way of representing a nonlinear effect of age.

For the time since the date of first employment, both linear and quadratic terms were considered. However, we could only detect significant differences among the

Table 2. Characteristics of the subcohorts with respect to age and pack-years of smoking on the date of first employment.

\begin{tabular}{|c|c|c|c|c|c|c|}
\hline \multirow{2}{*}{ Type of exposure } & \multicolumn{3}{|c|}{ Age (years) } & \multicolumn{3}{|c|}{ Pack-years } \\
\hline & Mean & $\mathrm{SD}$ & Range & Mean & $\mathrm{SD}$ & Range \\
\hline \multicolumn{7}{|l|}{ Polyvinyl chloride } \\
\hline $\begin{array}{l}<1.25 \text { pack-years }^{a}(\mathrm{~N}=5) \\
\geq 1.25 \text { pack-years }(\mathrm{N}=24)\end{array}$ & $\begin{array}{l}27.5 \\
30.0\end{array}$ & $\begin{array}{r}10.1 \\
6.4\end{array}$ & $\begin{array}{l}18-38 \\
20-46\end{array}$ & $\begin{array}{l}0.2 \\
9.8\end{array}$ & $\begin{array}{l}0.4 \\
6.4\end{array}$ & $\begin{array}{l}0.00-0.97 \\
1.32-29.00\end{array}$ \\
\hline \multicolumn{7}{|l|}{ Cement } \\
\hline $\begin{array}{l}<1.25 \text { pack-years }^{a}(N=17) \\
\geq 1.25 \text { pack-years }(N=19)\end{array}$ & $\begin{array}{l}28.1 \\
28.2\end{array}$ & $\begin{array}{l}7.0 \\
6.1\end{array}$ & $\begin{array}{l}18-40 \\
18-39\end{array}$ & $\begin{array}{l}0.1 \\
5.7\end{array}$ & $\begin{array}{l}1.1 \\
6.5\end{array}$ & $\begin{array}{l}0.00-1.07 \\
1.37-24.80\end{array}$ \\
\hline \multicolumn{7}{|l|}{ Asbestos } \\
\hline $\begin{array}{l}\text { Slight } \\
\quad<1.25 \text { pack-years }{ }^{a}(\mathrm{~N}=17) \\
\geq 1.25 \text { pack-years }(\mathrm{N}=31)\end{array}$ & $\begin{array}{l}20.5 \\
32.9\end{array}$ & $\begin{array}{l}7.0 \\
7.2\end{array}$ & $\begin{array}{l}17-36 \\
17-44\end{array}$ & $\begin{array}{l}0.1 \\
9.5\end{array}$ & $\begin{array}{l}1.1 \\
5.6\end{array}$ & $\begin{array}{l}0.00-0.90 \\
1.25-23.27\end{array}$ \\
\hline $\begin{array}{l}\text { Heavy } \\
\quad<1.25 \text { pack-years }{ }^{a}(N=4) \\
\geq 1.25 \text { pack-years }(N=9)\end{array}$ & $\begin{array}{l}27.7 \\
34.1\end{array}$ & $\begin{array}{l}8.4 \\
8.1\end{array}$ & $\begin{array}{l}18-38 \\
21-43\end{array}$ & $\begin{array}{c}0 \\
12.1\end{array}$ & 9.0 & $2.37-25.55$ \\
\hline
\end{tabular}

a Nonsmokers included. 
exposure groups when using quadratic terms (which imply accelerated decline).

The effect of smoking was analyzed in detail after such variables as pack-years of smoking and the average number of cigarettes per day were introduced into the model. In order to construct the variable packyears, we used two different measures of smoking time, ie, total smoking time to the moment of each survey and smoking time up to the first survey and from survey to survey. The construction of the two groups, nonsmokers-light smokers $(<1.25$ pack-years at the date of first employment) and heavy smokers ( $\geq 1.25$ pack-years), was decided on the basis of this preliminary analysis. At the time of the third survey (1984) ex-smokers were considered separately from smokers in an effort to evaluate whether, between them, there was (i) an early difference in FVC and $\mathrm{FEV}_{1.0}$ (difference in intercepts at the date of first employment), (ii) an increasing difference with length of employment (difference in the regression coefficients for the years of employment or the square of the years of employment), and (iii) different effects of duration of smoking (difference in regression coefficients for pack-years of smoking). No significant difference was found between the smokers and ex-smokers. The estimation process was based on the GLIM package (23).

\section{Results}

The total dust concentrations, collected in 1973 in the PVC department, the cement factory, and the asbestoscement mixing area and in 1978 only in the cement factory, suggest a heavy exposure to asbestos and cement, with a slight improvement between 1973 and 1978 as regards cement exposure (table 3 ).

In 1973 the heavy smokers were older than the nonsmokers-light smokers in the groups exposed to PVC and asbestos (table 4). This difference was particularly great in the two asbestos groups.

Table 5 shows the results of the lung function tests carried out in 1973, 1980, and 1984. The 1973 values for FVC and $\mathrm{FEV}_{1.0}$, when expressed as percentages of the predicted (15), were slightly lower among the

Table 3. Total dust concentrations $\left(\mathrm{mg} / \mathrm{m}^{3}\right)$ in 1973 and 1978.

\begin{tabular}{|c|c|c|c|c|}
\hline Location & $\begin{array}{c}\text { Number of } \\
\text { samples }\end{array}$ & Range & $\begin{array}{c}\text { Geometric } \\
\text { mean }\end{array}$ & SE \\
\hline \multicolumn{5}{|c|}{$\begin{array}{l}\text { Polyvinyl chloride } \\
\text { department }\end{array}$} \\
\hline 1973 & 10 & $0.9-16.1$ & 3.3 & 1.3 \\
\hline \multicolumn{5}{|c|}{ Cement factory } \\
\hline $\begin{array}{l}1973 \\
1978\end{array}$ & $\begin{array}{l}13 \\
31\end{array}$ & $\begin{array}{l}1.4-56.0 \\
0.5-147.0\end{array}$ & $\begin{array}{l}7.4 \\
5.3\end{array}$ & $\begin{array}{l}1.0 \\
0.8\end{array}$ \\
\hline \multicolumn{5}{|c|}{$\begin{array}{l}\text { Asbestos-cement } \\
\text { mixing area }\end{array}$} \\
\hline 1973 & 6 & $3.3-32.1$ & 10.9 & 1.4 \\
\hline
\end{tabular}

Table 4. Mean ages and heights of the 1973 subcohorts.

\begin{tabular}{|c|c|c|c|c|}
\hline \multirow{2}{*}{ Type of exposure } & \multicolumn{2}{|c|}{ Age (years) } & \multicolumn{2}{|c|}{ Height $(\mathrm{cm})$} \\
\hline & Mean & SD & Mean & SD \\
\hline \multicolumn{5}{|l|}{ Polyvinyl chloride } \\
\hline $\begin{array}{l}<1.25 \text { pack-years }^{a} \\
\geq 1.25 \text { pack-years }^{a}\end{array}$ & $\begin{array}{l}32.7 \\
35.6\end{array}$ & $\begin{array}{r}11.0 \\
7.8\end{array}$ & $\begin{array}{l}166.6 \\
168.9\end{array}$ & $\begin{array}{l}7.2 \\
5.9\end{array}$ \\
\hline \multicolumn{5}{|l|}{ Cement } \\
\hline $\begin{array}{l}<1.25 \text { pack-years }^{a} \\
\geq 1.25 \text { pack-years }^{a}\end{array}$ & $\begin{array}{l}37.9 \\
37.9\end{array}$ & $\begin{array}{l}5.8 \\
8.3\end{array}$ & $\begin{array}{l}169.8 \\
168.8\end{array}$ & $\begin{array}{l}5.4 \\
3.1\end{array}$ \\
\hline \multicolumn{5}{|l|}{ Asbestos } \\
\hline $\begin{array}{l}\text { Slight } \\
<1.25 \text { pack-years }^{a} \\
\geq 1.25 \text { pack-years }^{a}\end{array}$ & $\begin{array}{l}28.8 \\
40.9\end{array}$ & $\begin{array}{l}4.9 \\
7.8\end{array}$ & $\begin{array}{l}170.2 \\
168.6\end{array}$ & $\begin{array}{l}5.4 \\
5.0\end{array}$ \\
\hline $\begin{array}{l}\text { Heavy } \\
\quad<1.25 \text { pack-years }^{a} \\
\geq 1.25 \text { pack-years }^{a}\end{array}$ & $\begin{array}{l}35.7 \\
41.6\end{array}$ & $\begin{array}{l}0.2 \\
8.1\end{array}$ & $\begin{array}{l}167.5 \\
167.7\end{array}$ & $\begin{array}{l}8.6 \\
6.3\end{array}$ \\
\hline
\end{tabular}

a On the date of first employment.

Table 5. Observed lung function levels of the subcohorts in the 1973, 1980, and 1984 surveys. (FVC=forced vital capacity, $\mathrm{FEV}_{1.0}=$ forced expiratory volume in $1 \mathrm{~s}$ )

\begin{tabular}{|c|c|c|c|c|c|c|c|c|c|c|c|c|}
\hline \multirow{3}{*}{ Type of exposure } & \multicolumn{6}{|c|}{ FVC (I) } & \multicolumn{6}{|c|}{$\mathrm{FEV}_{1.0}(\mathrm{l})$} \\
\hline & \multicolumn{2}{|c|}{1973} & \multicolumn{2}{|c|}{1980} & \multicolumn{2}{|c|}{1984} & \multicolumn{2}{|c|}{1973} & \multicolumn{2}{|c|}{1980} & \multicolumn{2}{|c|}{1984} \\
\hline & Mean & SD & Mean & SD & Mean & SD & Mean & SD & Mean & SD & Mean & SD \\
\hline \multicolumn{13}{|l|}{ Polyvinyl chloride } \\
\hline $\begin{array}{l}<1.25 \text { pack-years }^{a} \\
\geq 1.25 \text { pack-years }^{a}\end{array}$ & $\begin{array}{l}4.91 \\
4.94\end{array}$ & $\begin{array}{l}0.56 \\
0.73\end{array}$ & $\begin{array}{l}4.67 \\
4.62\end{array}$ & $\begin{array}{l}0.71 \\
0.67\end{array}$ & $\begin{array}{l}4.54 \\
4.37\end{array}$ & $\begin{array}{l}0.72 \\
0.78\end{array}$ & $\begin{array}{l}4.11 \\
4.08\end{array}$ & $\begin{array}{l}0.37 \\
0.54\end{array}$ & $\begin{array}{l}3.92 \\
3.72\end{array}$ & $\begin{array}{l}0.53 \\
0.59\end{array}$ & $\begin{array}{l}3.84 \\
3.53\end{array}$ & $\begin{array}{l}0.56 \\
0.67\end{array}$ \\
\hline \multicolumn{13}{|l|}{ Cement } \\
\hline $\begin{array}{l}<1.25 \text { pack-years }^{a} \\
\geq 1.25 \text { pack-years }^{a}\end{array}$ & $\begin{array}{l}5.20 \\
4.82\end{array}$ & $\begin{array}{l}0.80 \\
0.77\end{array}$ & $\begin{array}{l}4.98 \\
4.66\end{array}$ & $\begin{array}{l}0.71 \\
0.63\end{array}$ & $\begin{array}{l}4.71 \\
4.37\end{array}$ & $\begin{array}{l}0.76 \\
0.76\end{array}$ & $\begin{array}{l}4.18 \\
3.99\end{array}$ & $\begin{array}{l}0.69 \\
0.82\end{array}$ & $\begin{array}{l}3.87 \\
3.85\end{array}$ & $\begin{array}{l}0.70 \\
0.79\end{array}$ & $\begin{array}{l}3.79 \\
3.54\end{array}$ & $\begin{array}{l}0.79 \\
0.77\end{array}$ \\
\hline \multicolumn{13}{|l|}{ Asbestos } \\
\hline $\begin{array}{l}\text { Slight } \\
<1.25 \text { pack-years }^{a} \\
\geq 1.25 \text { pack-years }^{a}\end{array}$ & $\begin{array}{l}5.36 \\
4.63\end{array}$ & $\begin{array}{l}0.64 \\
0.81\end{array}$ & $\begin{array}{l}5.02 \\
4.36\end{array}$ & $\begin{array}{l}0.58 \\
0.74\end{array}$ & $\begin{array}{l}4.87 \\
4.10\end{array}$ & $\begin{array}{l}0.58 \\
0.82\end{array}$ & $\begin{array}{l}4.51 \\
3.67\end{array}$ & $\begin{array}{l}0.51 \\
0.71\end{array}$ & $\begin{array}{l}4.17 \\
3.37\end{array}$ & $\begin{array}{l}0.51 \\
0.72\end{array}$ & $\begin{array}{l}4.01 \\
3.20\end{array}$ & $\begin{array}{l}0.42 \\
0.77\end{array}$ \\
\hline $\begin{array}{l}\text { Heavy } \\
\quad<1.25 \text { pack-years }^{a} \\
\geq 1.25 \text { pack-years }^{a}\end{array}$ & $\begin{array}{l}4.46 \\
4.35\end{array}$ & $\begin{array}{l}0.83 \\
0.83\end{array}$ & $\begin{array}{l}3.94 \\
3.89\end{array}$ & $\begin{array}{l}1.17 \\
0.77\end{array}$ & $\begin{array}{l}3.78 \\
3.38\end{array}$ & $\begin{array}{l}0.92 \\
1.11\end{array}$ & $\begin{array}{l}3.72 \\
3.47\end{array}$ & $\begin{array}{l}0.88 \\
0.73\end{array}$ & $\begin{array}{l}3.26 \\
2.99\end{array}$ & $\begin{array}{l}0.99 \\
0.64\end{array}$ & $\begin{array}{l}3.09 \\
2.60\end{array}$ & $\begin{array}{l}0.83 \\
0.90\end{array}$ \\
\hline
\end{tabular}

a On the date of first employment. 
Table 6. Lung function values (\% predicted) of the subcohorts in the 1973,1980 , and 1984 surveys. (FVC = forced vital capacity, $\mathrm{FEV}_{1.0}=$ forced expired volume in $\left.1 \mathrm{~s}\right)$

\begin{tabular}{|c|c|c|c|c|c|c|c|c|c|c|c|c|}
\hline \multirow{3}{*}{ Type of exposure } & \multicolumn{6}{|c|}{$\mathrm{FVC}^{\mathrm{a}}(\mathrm{I})$} & \multicolumn{6}{|c|}{$\mathrm{FEV}_{1.0^{2}(I)}$} \\
\hline & \multicolumn{2}{|c|}{1973} & \multicolumn{2}{|c|}{1980} & \multicolumn{2}{|c|}{1984} & \multicolumn{2}{|c|}{1973} & \multicolumn{2}{|c|}{1980} & \multicolumn{2}{|c|}{1984} \\
\hline & Mean & SD & Mean & SD & Mean & SD & Mean & SD & Mean & SD & Mean & SD \\
\hline \multicolumn{13}{|l|}{ Polyvinyl chioride } \\
\hline $\begin{array}{l}<1.25 \text { pack-years }{ }^{b} \\
\geq 1.25 \text { pack-years }^{b}\end{array}$ & $\begin{array}{l}112.6 \\
110.1\end{array}$ & $\begin{array}{l}13.3 \\
11.9\end{array}$ & $\begin{array}{l}111.7 \\
108.4\end{array}$ & $\begin{array}{l}13.5 \\
12.4\end{array}$ & $\begin{array}{l}111.2 \\
104.4\end{array}$ & $\begin{array}{l}13.2 \\
13.3\end{array}$ & $\begin{array}{l}115.0 \\
112.4\end{array}$ & $\begin{array}{r}11.2 \\
9.8\end{array}$ & $\begin{array}{l}116.7 \\
109.0\end{array}$ & $\begin{array}{r}8.8 \\
12.6\end{array}$ & $\begin{array}{l}117.6 \\
105.8\end{array}$ & $\begin{array}{l}11.4 \\
14.1\end{array}$ \\
\hline \multicolumn{13}{|l|}{ Cement } \\
\hline $\begin{array}{l}<1.25 \text { pack-years }{ }^{b} \\
\geq 1.25 \text { pack-years }^{b}\end{array}$ & $\begin{array}{l}116.4 \\
109.2\end{array}$ & $\begin{array}{l}13.9 \\
14.3\end{array}$ & $\begin{array}{l}116.9 \\
111.3\end{array}$ & $\begin{array}{l}12.8 \\
13.5\end{array}$ & $\begin{array}{l}113.9 \\
107.2\end{array}$ & $\begin{array}{l}13.5 \\
14.9\end{array}$ & $\begin{array}{l}116.2 \\
112.2\end{array}$ & $\begin{array}{l}16.6 \\
19.5\end{array}$ & $\begin{array}{l}114.0 \\
114.8\end{array}$ & $\begin{array}{l}18.2 \\
19.5\end{array}$ & $\begin{array}{l}115.3 \\
109.4\end{array}$ & $\begin{array}{l}20.6 \\
18.7\end{array}$ \\
\hline \multicolumn{13}{|l|}{ Asbestos } \\
\hline $\begin{array}{l}\text { Slight } \\
<1.25 \text { pack-years }{ }^{b} \\
\geq 1.25 \text { pack-years }^{b}\end{array}$ & $\begin{array}{l}112.4 \\
107.2\end{array}$ & $\begin{array}{l}12.6 \\
13.8\end{array}$ & $\begin{array}{l}110.5 \\
106.5\end{array}$ & $\begin{array}{l}12.0 \\
13.8\end{array}$ & $\begin{array}{l}109.9 \\
102.4\end{array}$ & $\begin{array}{l}14.8 \\
15.9\end{array}$ & $\begin{array}{l}116.2 \\
105.7\end{array}$ & $\begin{array}{l}11.9 \\
14.1\end{array}$ & $\begin{array}{l}113.8 \\
103.3\end{array}$ & $\begin{array}{l}13.1 \\
15.1\end{array}$ & $\begin{array}{l}113.0 \\
100.5\end{array}$ & $\begin{array}{l}15.9 \\
17.8\end{array}$ \\
\hline $\begin{array}{l}\text { Heavy } \\
<1.25 \text { pack-years }^{b} \\
\geq 1.25 \text { pack-years }^{\mathrm{b}}\end{array}$ & $\begin{array}{l}102.0 \\
102.3\end{array}$ & $\begin{array}{l}9.5 \\
7.5\end{array}$ & $\begin{array}{l}94.3 \\
97.0\end{array}$ & $\begin{array}{l}20.6 \\
10.1\end{array}$ & $\begin{array}{l}93.9 \\
85.4\end{array}$ & $\begin{array}{l}22.4 \\
21.7\end{array}$ & $\begin{array}{l}104.1 \\
101.9\end{array}$ & $\begin{array}{l}11.9 \\
11.9\end{array}$ & $\begin{array}{l}97.6 \\
93.6\end{array}$ & $\begin{array}{l}20.9 \\
10.5\end{array}$ & $\begin{array}{l}96.3 \\
83.1\end{array}$ & $\begin{array}{l}26.4 \\
23.0\end{array}$ \\
\hline
\end{tabular}

a FVC and $\mathrm{FEV}_{10}$ predicted values according to Knudson et al (15)

b On the date of first employment.

Table 7. Age, height, and lung function characteristics, in 1973, of the subjects lost to follow-up. (FVC= forced vital capacity, $\mathrm{FEV}_{1.0}=$ forced expiratory volume in $1 \mathrm{~s}$ )

\begin{tabular}{|c|c|c|c|c|c|c|c|c|c|c|c|c|}
\hline \multirow[t]{2}{*}{ Type of exposure } & \multicolumn{2}{|c|}{$\begin{array}{c}\text { Age } \\
\text { (years) }\end{array}$} & \multicolumn{2}{|c|}{$\begin{array}{l}\text { Height } \\
(\mathrm{cm})\end{array}$} & \multicolumn{2}{|c|}{$\begin{array}{c}\text { FVC } \\
\text { (I) }\end{array}$} & \multicolumn{2}{|c|}{$\begin{array}{c}\text { FVC } \\
\text { (\% pre- } \\
\text { dicted) }\end{array}$} & \multicolumn{2}{|c|}{$\mathrm{FEV}_{1.0}$} & \multicolumn{2}{|c|}{$\begin{array}{l}\mathrm{FEV}_{10 .} \\
\text { ( } \% \text { pre- } \\
\text { dicted) }^{\mathrm{a}}\end{array}$} \\
\hline & Mean & SD & Mean & SD & Mean & $S D$ & Mean & SD & Mean & SD & Mean & SD \\
\hline \multicolumn{13}{|l|}{ Polyvinyl chloride } \\
\hline $\begin{array}{l}\text { Present } 1973^{b}\langle N=4) \\
\text { Present } 1973 \text { and } 1980^{c}(N=1)\end{array}$ & $\begin{array}{l}39.0 \\
32.4\end{array}$ & 15.4 & $\begin{array}{l}176.0 \\
170.0\end{array}$ & 4.0 & $\begin{array}{l}5.70 \\
4.45\end{array}$ & 1.18 & $\begin{array}{r}119.1 \\
97.0\end{array}$ & 12.2 & $\begin{array}{l}4.41 \\
3.10\end{array}$ & 1.20 & $\begin{array}{r}111.9 \\
83.6\end{array}$ & 17.8 \\
\hline \multicolumn{13}{|l|}{ Cement } \\
\hline $\begin{array}{l}\text { Present } 1973^{\mathrm{b}}(\mathrm{N}=21) \\
\text { Present } 1973 \text { and } 1980^{\mathrm{c}}(\mathrm{N}=11)\end{array}$ & $\begin{array}{l}44.3 \\
45.5\end{array}$ & $\begin{array}{r}11.0 \\
8.0\end{array}$ & $\begin{array}{l}172.3 \\
167.0\end{array}$ & $\begin{array}{l}5.5 \\
6.0\end{array}$ & $\begin{array}{l}4.94 \\
4.45\end{array}$ & $\begin{array}{l}0.96 \\
0.70\end{array}$ & $\begin{array}{l}113.2 \\
107.8\end{array}$ & $\begin{array}{l}15.1 \\
18.6\end{array}$ & $\begin{array}{l}3.95 \\
3.62\end{array}$ & $\begin{array}{l}0.96 \\
0.73\end{array}$ & $\begin{array}{l}110.7 \\
109.5\end{array}$ & $\begin{array}{l}18.8 \\
21.9\end{array}$ \\
\hline \multicolumn{13}{|l|}{ Asbestos } \\
\hline $\begin{array}{l}\text { Present } 1973^{\mathrm{b}}(\mathrm{N}=12) \\
\text { Present } 1973^{2} \text { and } 1980^{\circ}(\mathrm{N}=4)\end{array}$ & $\begin{array}{l}41.6 \\
46.2\end{array}$ & $\begin{array}{r}10.4 \\
6.4\end{array}$ & $\begin{array}{l}169.8 \\
166.5\end{array}$ & $\begin{array}{l}4.8 \\
5.2\end{array}$ & $\begin{array}{l}4.81 \\
4.81\end{array}$ & $\begin{array}{l}0.80 \\
1.08\end{array}$ & $\begin{array}{l}112.2 \\
119.1\end{array}$ & $\begin{array}{l}11.4 \\
27.6\end{array}$ & $\begin{array}{l}3.86 \\
3.81\end{array}$ & $\begin{array}{l}0.87 \\
0.80\end{array}$ & $\begin{array}{l}110.0 \\
118.5\end{array}$ & $\begin{array}{l}17.3 \\
26.6\end{array}$ \\
\hline
\end{tabular}

a Predicted values according to Knudson et al (15).

b Absent 1980 and 1984.

c Absent 1984.

Table 8. Mean pack-years of smoking of the subcohorts in the 1973,1980 , and 1984 surveys.

\begin{tabular}{|c|c|c|c|c|c|c|}
\hline \multirow{2}{*}{ Type of exposure } & \multicolumn{2}{|c|}{1973} & \multicolumn{2}{|c|}{1980} & \multicolumn{2}{|c|}{1984} \\
\hline & Mean & SD & Mean & SD & Mean & SD \\
\hline \multicolumn{7}{|l|}{ Polyvinyl chloride } \\
\hline $\begin{array}{l}<1.25 \text { pack-years }{ }^{a} \\
\geq 1.25 \text { pack-years }^{a}\end{array}$ & $\begin{array}{r}0.5 \\
13.7\end{array}$ & $\begin{array}{l}0.7 \\
6.9\end{array}$ & $\begin{array}{r}2.0 \\
17.9\end{array}$ & $\begin{array}{l}2.2 \\
7.8\end{array}$ & $\begin{array}{r}2.6 \\
19.4\end{array}$ & $\begin{array}{l}3.6 \\
8.8\end{array}$ \\
\hline \multicolumn{7}{|l|}{ Cement } \\
\hline $\begin{array}{l}<1.25 \text { pack-years }{ }^{a} \\
\geqslant 1.25 \text { pack-years }\end{array}$ & $\begin{array}{l}1.0 \\
9.8\end{array}$ & $\begin{array}{l}3.3 \\
8.3\end{array}$ & $\begin{array}{r}1.6 \\
13.0\end{array}$ & $\begin{array}{r}4.9 \\
10.5\end{array}$ & $\begin{array}{r}2.0 \\
15.3\end{array}$ & $\begin{array}{r}6.2 \\
11.8\end{array}$ \\
\hline \multicolumn{7}{|l|}{ Asbestos } \\
\hline \multicolumn{7}{|l|}{ Slight } \\
\hline $\begin{array}{l}<1.25 \text { pack-years }{ }^{\mathrm{a}} \\
\geq 1.25 \text { pack-years }^{\mathrm{a}}\end{array}$ & $\begin{array}{r}3.7 \\
14.4\end{array}$ & $\begin{array}{l}3.7 \\
7.8\end{array}$ & $\begin{array}{r}6.9 \\
18.9\end{array}$ & $\begin{array}{l}6.6 \\
9.5\end{array}$ & $\begin{array}{r}8.8 \\
20.8\end{array}$ & $\begin{array}{r}8.2 \\
10.0\end{array}$ \\
\hline \multicolumn{7}{|l|}{ Heavy } \\
\hline $\begin{array}{l}<1.25 \text { pack-years }^{\mathrm{a}} \\
\geq 1.25 \text { pack-years } \mathrm{a}\end{array}$ & $\begin{array}{r}1.4 \\
17.1 \\
\end{array}$ & $\begin{array}{l}2.8 \\
9.3 \\
\end{array}$ & $\begin{array}{r}3.4 \\
22.2 \\
\end{array}$ & $\begin{array}{r}5.4 \\
12.3 \\
\end{array}$ & $\begin{array}{r}4.8 \\
23.4\end{array}$ & $\begin{array}{r}6.8 \\
12.9 \\
\end{array}$ \\
\hline
\end{tabular}

a On the date of first employment.

heavy smokers than among the nonsmokers-light smokers (table 6). In all the exposure groups the FVC and $\mathrm{FEV}_{1.0}$ values ( $\%$ predicted) tended to decrease during the follow-up, particularly for those with heavy exposure to asbestos and the heavy smokers in the PVC and slight asbestos exposure groups.

The subjects lost to follow-up in 1980 and 1984 were older than those who completed all three surveys (table 7). Furthermore, the cement workers lost to followup had lower mean FVC and $\mathrm{FEV}_{1.0}(\%$ predicted) (15) values in 1973 than those who were followed-up (table 4). The pack-years of smoking tended to be fewer for the cement workers and more for those with heavy exposure to asbestos (table 8).

The FVC and $\mathrm{FEV}_{1.0}$ values of the 126 subjects studied were divided into four exposure groups, two smoking categories and three age classes and regressed on height, years of employment, and the square of the years of employment (table 9). The equations thus obtained have been used in figure 1 to illustrate the lung function decline of the four exposure groups. The decline of FVC and $\mathrm{FEV}_{1.0}$ in the nonsmokers-light smokers was linear only among the cement workers; 
it accelerated with length of employment in the PVC and asbestos groups. The decrease in the FVC was slower in the cement group and faster in the heavy asbestos exposure group. Workers with PVC and slight asbestos exposure showed the same amount of decline. The decrease in $\mathrm{FEV}_{1.0}$ was very similar to that of FVC.

After adjustment for height, age, and smoking habits on the date of first employment, our model (see table 9) indicated that the heavy smokers of the four employment groups had predicted $\mathrm{FVC}$ and $\mathrm{FEV}_{1.0}$ values that were, respectively, 196 and $214 \mathrm{ml}$ lower than those of the nonsmokers-light smokers; this difference remained constant over time. Figure 2 provides a visual comparison of the fitted and observed values. The values presented are averages of the original values within nine three-year classes of employment duration. It should be remembered that there were three observed values for each subject. Figure 2 shows the mean observed and predicted values of FVC and $\mathrm{FEV}_{1.0}$ during 20 or more years of employment in the PVC and cement factories and years since first employment in the asbestos cement factory. The model provides a good fit to the mean observed values for the heavy smokers in all the groups. As regards nonsmokers-light smokers, the fit of the model was good for the observed values corresponding to 12 years or more of employment. For the first 12 years of employment it was fairly good for the PVC and slight asbestos exposure groups, but poor for the cement and heavy asbestos exposure groups. Such discrepancy between the observed and predicted values was probably due to the small number of observed values for the first 12 years of employment, while the irregular pattern of FVC and $\mathrm{FEV}_{1.0}$ can be explained by the difference in age distribution between the classes of employment duration. Cessation of asbestos exposure did not seem to affect lung function decline. At the time of the 1984 survey, asbestos exposure had been discontinued an average of $\mathbf{1 1 . 1}$ years for the nonsmokers-light smokers and 7.8 years for the heavy smokers with previous slight exposure and an average of 5.6 years for the nonsmokers-light smokers and 8.0 years for the heavy smokers with previous heavy exposure to asbestos.

Twenty years after first exposure the excessive decline of the FVC and $\mathrm{FEV}_{1.0}$ in the heavy asbestos exposure group could be estimated to be about 450 $500 \mathrm{ml}$ more than that of the PVC and slight asbestos

Table 9. Estimated parameters of the regression equations for longitudinal decline in forced vital capacity (FVC) and forced expiratory volume in $1 \mathrm{~s}\left(\mathrm{FEV}_{1.0}\right)$ in the 126 subjects studied from 1973 to 1984 .

\begin{tabular}{|c|c|c|c|c|}
\hline & \multicolumn{2}{|c|}{ FVC (I) } & \multicolumn{2}{|c|}{$\mathrm{FEV}_{1.0}$ (I) } \\
\hline & Mean & SE & Mean & SE \\
\hline \multicolumn{5}{|l|}{ Intercepts } \\
\hline $\begin{array}{l}\text { Age }<25 \text { years }{ }^{\mathrm{a}} \\
\text { Age } 25-34 \text { years } \\
\text { Age }>34 \text { years }\end{array}$ & $\begin{array}{l}5.625 \\
5.387 \\
4.864\end{array}$ & $\begin{array}{l}0.101 \\
0.117 \\
0.132\end{array}$ & $\begin{array}{l}4.730 \\
4.483 \\
3.947\end{array}$ & $\begin{array}{l}0.091 \\
0.105 \\
0.119\end{array}$ \\
\hline Smoking status ${ }^{b}$ & -0.196 & 0.105 & -0.214 & 0.095 \\
\hline \multicolumn{5}{|l|}{ Regression coefficients } \\
\hline $\begin{array}{l}\text { Centered height (cm) }{ }^{c} \\
\text { Employment (years) } \\
\text { Polyvinyi chloride and }^{\mathrm{c}} \\
\text { slight asbestos }\end{array}$ & $\begin{array}{r}0.070 \\
-0.035\end{array}$ & $\begin{array}{l}0.009 \\
0.004\end{array}$ & $\begin{array}{r}0.059 \\
-0.034\end{array}$ & $\begin{array}{l}0.008 \\
0.004\end{array}$ \\
\hline $\begin{array}{l}\text { exposure (years })^{d} \\
\text { Cement exposure } \\
\text { (years }^{2} \text { ) } \\
\text { Heavy asbestos } \\
\left.\text { exposure (years }{ }^{2}\right)^{d}\end{array}$ & $\begin{array}{c}-0.0005^{*} \\
\text { NSe } \\
-0.0018^{*}\end{array}$ & 0.0002 & $\begin{array}{l}-0.0004^{* *} \\
\text { NS }{ }^{*} \\
-0.0015^{* *}\end{array}$ & 0.0002 \\
\hline
\end{tabular}

a Age at first employment.

- Heavy smokers ( $\geq 1.25$ pack-years) - nonsmokers-light smokers $(<1.25$ pack-years) at first employment.

Centered height $=$ height - average height

- Centered height $=$ height - average height.

e NS = quadratic coefficient for cement exposure was not significant. * $t=4.12, P<0.001{ }^{* *} t=4.09, P<0.001$.
F V C

$$
\text { LITERS }
$$

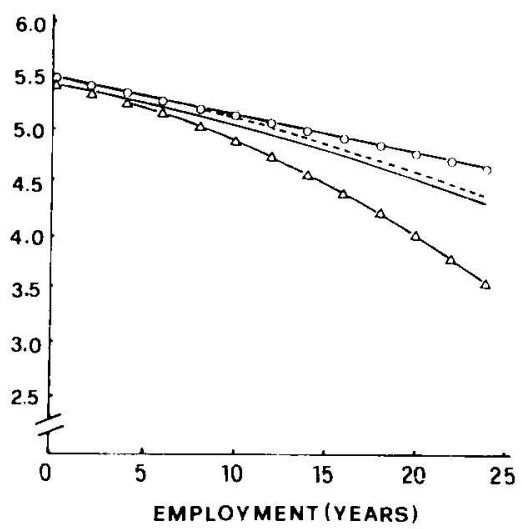

$$
F E V_{1.0}
$$

\section{LITRES}

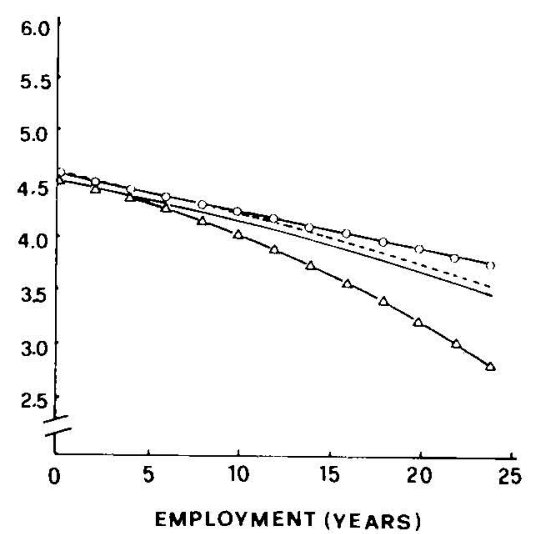

Figure 1. Predicted decline in forced vital capacity $(F V C)$ and forced expiratory volume in $1 \mathrm{~s}\left(F E V_{1.0}\right)$ for the nonsmokers-light smokers according to our model. $(-=$ workers exposed to polyvinyl chloride (PVC), $0-0=$ workers exposed to cement, $\cdots=$ workers with slight asbestos exposure, $\Delta--\Delta=$ workers with heavy asbestos exposure) 


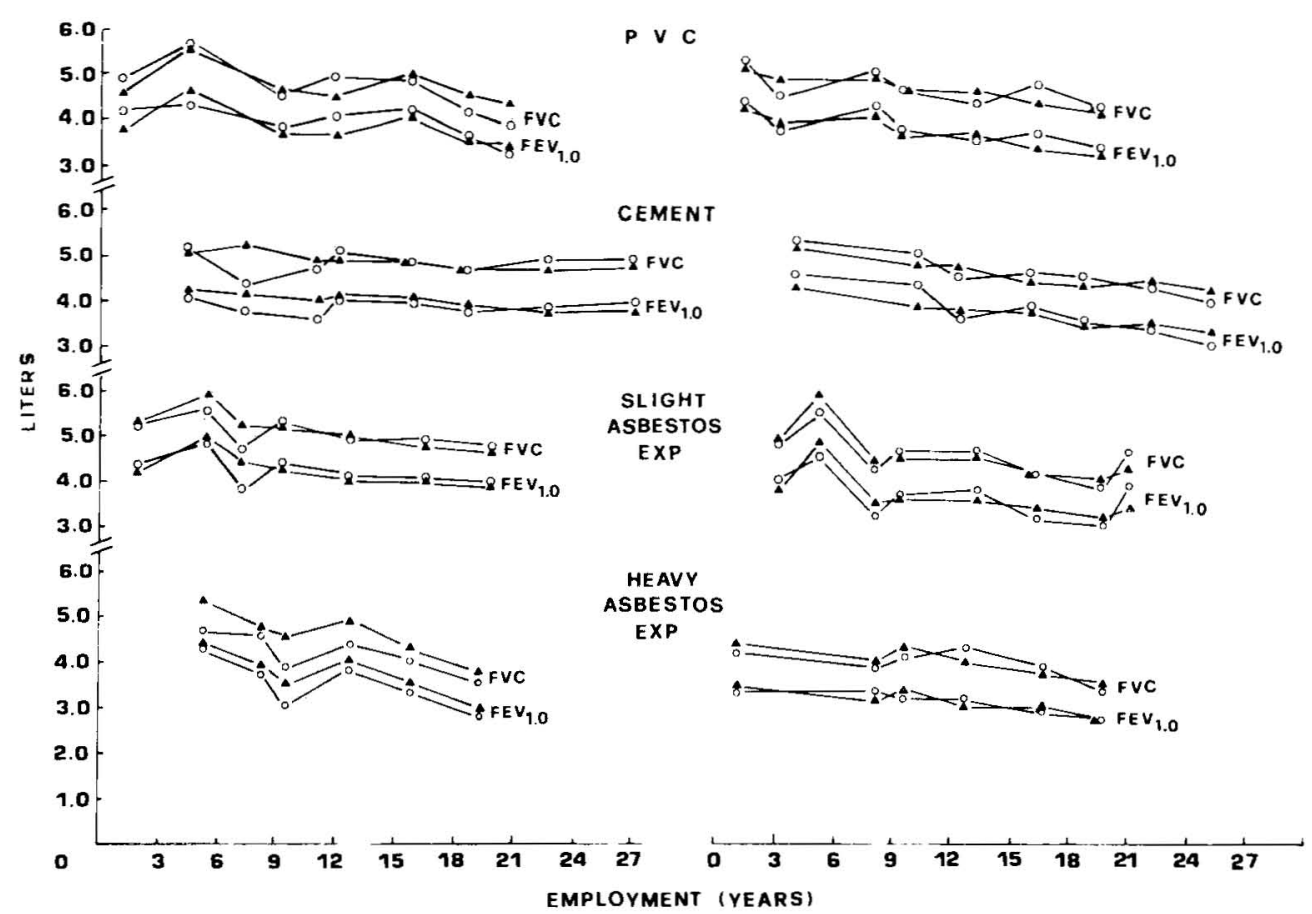

Figure 2. Fit of the model to the mean observed values of forced vital capacity (FVC) and forced expiratory volume in $1 \mathrm{~s}$ (FEV $\left.{ }_{1.0}\right)$ ( $P V C=$ polyvinyl chloride, $E X P=$ exposure,$O=$ observed values, $\Delta=$ predicted values according to our model)

Table 10. Predicted forced vital capacity (FVC) and forced expiratory volume in $1 \mathrm{~s}\left(\mathrm{FEV}_{10}\right)$ values [derived from our model (see table 9)] at initial employment and after 10 and 20 years.

\begin{tabular}{|c|c|c|c|c|c|c|}
\hline \multirow{3}{*}{ Type of exposure } & \multicolumn{6}{|c|}{ Exposure } \\
\hline & \multicolumn{2}{|c|}{0 year } & \multicolumn{2}{|c|}{10 years } & \multicolumn{2}{|c|}{20 years } \\
\hline & $\begin{array}{l}\text { FVC } \\
\text { (I) }\end{array}$ & $\underset{\text { (I) }}{\mathrm{FEV}_{1.0}}$ & $\underset{\text { (I) }}{\mathrm{FVC}}$ & $\underset{\text { (I) }}{\mathrm{FEV}_{1.0}}$ & $\begin{array}{l}\text { FVC } \\
\text { (I) }\end{array}$ & $\mathrm{FEV}_{1.0}$ \\
\hline Cement & 5.00 & 4.00 & 4.65 & 3.66 & 4.30 & 3.32 \\
\hline $\begin{array}{l}\text { Polyvinyl chloride and } \\
\text { slight asbestos exposure }\end{array}$ & 5.00 & 4.00 & 4.60 & 3.62 & 4.11 & 3.16 \\
\hline Heavy asbestos exposure ${ }^{a}$ & 5.00 & 4.00 & 4.47 & 3.50 & 3.59 & 2.70 \\
\hline
\end{tabular}

a Years from first employment for asbestos workers.

exposure groups and $600-700 \mathrm{ml}$ more than that of the cement workers (table 10).

\section{Discussion}

The results of this study may stimulate discussion of the following points: (i) the agreement and discrepancies between the results of this investigation and our previous study (25), (ii) the acceleration of FVC and $\mathrm{FEV}_{1.0}$ loss with years from first asbestos exposure, (iii) the combined effect of dust and cigarette smoke exposure, (iv) the noneffect of cessation of asbestos exposure on lung function decline, (v) a possible sur- vivor effect on workers exposed to cement, (vi) the importance of considering lung function decrease from first exposure rather than from first survey.

In agreement with the 1973 and 1980 surveys, we found that asbestos workers had a faster decline in FVC and FEV $_{1.0}$ between 1973 and 1984 than the PVC and cement workers. FVC and FEV ${ }_{1.0}$ loss with length of employment was linear for the cement workers, slightly accelerated for PVC and the slight asbestos exposure groups, and very accelerated for those with heavy exposure to asbestos.

In the few longitudinal studies on the lung function of workers exposed to asbestos $(2,11,13,20,21)$ there have usually been only two observations for each subject; in such cases it is impossible to obtain any infor- 
mation regarding possible deviation from linearity for individual subjects. In our study, which included three observations for each subject, a parabola was the model that best fit the data. Several other longitudinal studies have shown that lung function loss increases with age in the general population $(6,8,14)$, in smokers (3), and in workers exposed to dust $(1,16)$. In spite of their results, these authors used a model based on a straight line, while a polynomial model might have been more appropriate (4).

The effect of asbestos exposure and cigarette smoke on lung function seemed less than additive in our previous study for the period 1973-1980. In the current study it was clearly additive. We also found the same difference between heavy smokers and nonsmokerslight smokers among workers exposed to PVC or cement. This additive effect of the combined exposure has been documented in other studies $(7,24)$. We were not able to demonstrate any difference in lung function decline between those who were smokers and exsmokers at the moment of the third survey; consequently, we did not exclude ex-smokers from the analysis, as had been suggested in a similar study (21).

Lung function decline increased with time despite the cessation of asbestos exposure that had occurred from 5.6 to 11.1 years before the 1984 survey. These results agree with those of other studies on lung function (21) and radiographic asbestosis (5).

Our results regarding cement workers may be biased, as only one attempt was made to find them for the 1980 and 1984 surveys. Indeed, in the cement group there was a substantial loss to follow-up (47.1\% from 1973 to 1984), and this loss may have provoked an underestimation of lung function decline in the subjects studied in all three surveys as the cement workers lost to follow-up had lower pulmonary function test values in the 1973 survey than those who were followed-up (tables 6 and 7).

Fletcher et al (8) emphasized the importance of estimating the amount of $\mathrm{FEV}_{1.0}$ lost before a longitudinal study; nevertheless, this aspect has seldom been considered (14). In our study the duration of the exposure at the first survey (1973) was carefully evaluated as a variable among and within the four groups. Disregarding this information would have caused a misinterpretation of the results. Indeed, the effect of the duration of exposure could have been incorrectly attributed to other factors (age, smoking, etc). In addition, if the lung function decline is not a straight line, as in our study, the average decline in a certain time interval depends on the duration of exposure.

In conclusion, our 11-year follow-up study confirms that heavy exposure to asbestos is associated with an excessive loss of ventilatory capacity. This loss increases with time after the first exposure and is unaffected even if the exposure has been discontinued for up to 10 years. The contribution of cigarette smoking to lung function decline seems of minor importance in comparison with that of asbestos.

\section{Acknowledgments}

We wish to thank Dr V Viola, Mr P Fratini, P Ardizzoni, S Locci and G Marini for their environmental analysis, Ms F Pierri and Mr O Gervasi for computer graphic support, Ms $\mathrm{K}$ Brandt Tonato and Mr P Raymer for their assistance with the preparation of the manuscript.

\section{References}

1. Attfield MD. Longitudinal decline in $\mathrm{FEV}_{1}$ in United States coalminers. Thorax 40 (1985) 132-137.

2. Becklake MR, Thomas D, Liddell FDK, McDonald JC. Follow-up respiratory measurements in Quebec chrysotile asbestos miners and millers. Scand $\mathbf{J}$ Work Environ Health 8 (1982): suppl 1, 105-110.

3. Bossé R, Sparrow D, Garvey AJ, Costa PT Jr, Weiss ST, Rowe JW. Cigarette smoking, aging, and decline in pulmonary function: A longitudinal study. Arch Environ Health 35 (1980) 247-252.

4. Burrows B, Lebowitz MD, Camilli AE, Knudson RJ. Longitudinal changes in forced expiratory volume in one second in adults: Methodologic considerations and findings in healthy nonsmokers. Am Rev Respir Dis 133 (1986) 974-980.

5. Cookson W, De Klerk N, Musk AW, Glancy JJ, Armstrong B, Hobbs M. The natural history of asbestosis in former crocidolite workers of Wittenoom Gorge. Am Rev Respir Dis 133 (1986) 994-998.

6. Ferris BG Jr, Higgins ITT, Higgins MW, Peters JM. Chronic nonspecific respiratory disease in Berlin, New Hampshire, 1961 to 1967. Am Rev Respir Dis 107 (1973) $110-122$.

7. Finkelstein M. Pulmonary function in asbestos cement workers: A dose-response study. Br J Ind Med 43 (1986) $406-413$.

8. Fletcher C, Peto R, Tinker C, Speizer FE. The natural history of chronic bronchitis and emphysema: An eightyear study of early chronic obstructive lung disease in working men in London. Oxford University Press, London 1976.

9. Hammad YY, Diem J, Weill H. Evaluation of dust exposure in asbestos cement manufacturing operations. Am Ind Hyg Assoc J 40 (1979) 490-495.

10. Hedenstierna $G$, Alexandersson R, Kolmodin-Hedman B, Szamosi A, Tollqvist J. Pleural plaques and lung function in construction workers exposed to asbestos. Eur J Respir Dis 62 (1981) 111-122.

11. Hilt B. Non-malignant asbestos diseases in workers in an electrochemical plant. Br J Ind Med 44 (1987) 621626.

12. Hilt B, Lien JT, Lund-Larsen PG. Lung function and respiratory symptoms in subjects with asbestos-related disorders: A cross-sectional study. Am J Ind Med 11 (1987) $517-528$

13. Jones RN, Diem JE, Glindmeyer H, Weill H, Gilson JC. Progression of asbestos radiographic abnormalities: Relationships to estimates of dust exposure and annual decline in lung function. In: Wagner JC, Davis W, ed. Biological effects of mineral fibres. Volume 2. International Agency for Research on Cancer, Lyon 1980, pp 537-543. (IARC scientific publications no 30).

14. Kauffmann F, Drouet D, Lellouch J, Brille D. Twelve years spirometric changes among Paris area workers. Int J Epidemiol 8 (1979) 201-212.

15. Knudson RJ, Slatin RC, Lebowitz MD, Burrows B. The maximal expiratory flow-volume curve: Normal standards, variability, and effects of age. Am Rev Respir Dis 113 (1976) $587-600$. 
16. Love RG, Miller BG. Longitudinal study of lung function in coal-miners. Thorax 37 (1982) 193-197.

17. McDonald JC, Becklake MR, Gibbs GW, McDonald $\mathrm{AD}$, Rossiter CE. The health of chrysotile asbestos mine and mill workers of Quebec. Arch Environ Health 28 (1974) $61-68$.

18. Mitchell CA, Charney M, Schoenberg JB. Early lung disease in asbestos-product workers. Lung 154 (1978) $261-272$.

19. Murphy RLH Jr, Ferris BG Jr, Burgess WA, Worcester $\mathrm{J}$, Gaensler EA. Effects of low concentrations of asbestos: Clinical, environmental, radiologic and epidemiologic observations in shipyard pipe coverers and controls. N Engl J Med 285 (1971) 1271-1278.

20. Murphy RLH Jr, Gaensler EA, Ferris BG, Fitzgerald M, Solliday N, Morrisey W. Diagnosis of "asbestosis": Observations from a longitudinal survey of shipyard pipe coverers. Am J Med 65 (1978) 488-498.

21. Ohlson C-G, Bodin L, Rydman T, Hogstedt C. Ventilatory decrements in former asbestos cement workers: A four year follow up. Br J Ind Med 42 (1985) 612-616.
22. Ohlson C-G, Rydman T, Sundell L, Bodin L, Hogstedt C. Decreased lung function in long-term asbestos cement workers: A cross-sectional study. Am J Ind Med 5 (1984) 359-366.

23. Payne CD, ed. The GLIM System - Release 3.77. Numerical Algorithms Group, Oxford 1985.

24. Samet JM, Epler GR, Gaensler EA, Rosner B. Absence of synergism between exposure to asbestos and cigarette smoking in asbestosis. Am Rev Respir Dis 120 (1979) $75-82$.

25. Siracusa A, Cicioni C, Volpi $R$, Canalicchi P, Brugnami G, Comodi AR, Abbritti G. Lung function among asbestos cement factory workers: Cross-sectional and longitudinal study. Am J Ind Med 5 (1984) 315-325.

26. Volpi R, Siracusa A, Cicioni C, Canalicchi P, Fiore M. Lung function among PVC, cement and asbestos cement factory workers: A longitudinal study. Med Lav 77 (1986) 106.

Received for publication: 9 November 1987 